Original article

\title{
The signaling pathway for aldosterone-induced mitochondrial production of superoxide anion in the myocardium
}

\author{
M.B. Nolly ${ }^{1}$, C.I. Caldiz ${ }^{1}$, A.M. Yeves, M.C. Villa-Abrille, P.E. Morgan, Nicolas Amado Mondaca, \\ Enrique L. Portiansky, G.E. Chiappe de Cingolani, H.E. Cingolani, I.L. Ennis *
}

Centro de Investigaciones Cardiovasculares, Facultad de Ciencias Médicas, UNLP-CONICET, Argentina

\section{A R T I C L E I N F O}

\section{Article history:}

Received 13 June 2013

Received in revised form 4 December 2013

Accepted 8 December 2013

Available online 16 December 2013

\section{Keywords:}

Mineralocorticoid receptor

Oxidative stress

SiRNA

Transactivation

\begin{abstract}
A B S T R A C T
Mineralocorticoid receptor (MR) antagonists decrease morbidity and mortality in heart failure patients for whom oxidative stress is usual; however, the underlying mechanism for this protection is unclear. Since aldosterone stimulates reactive oxygen species (ROS) production in several tissues, we explored its effect and the intracellular pathway involved in the rat myocardium. Aldosterone dose-dependently increased $\mathrm{O}_{2}^{-}$production in myocardial slices. At $10 \mathrm{nmol} / \mathrm{L}$, aldosterone increased $\mathrm{O}_{2}^{-}$to $165 \pm 8.8 \%$ of control, an effect prevented not only by the MR antagonists eplerenone and spironolactone ( $107 \pm 7.8$ and $103 \pm 5.3 \%$, respectively) but also by AG1478 (105 $\pm 8.0 \%$ ), antagonist of the EGF receptor (EGFR). Similar results were obtained by silencing MR expression through the direct intramyocardial injection of a lentivirus coding for a siRNA against the MR. The aldosterone effect on $\mathrm{O}_{2}^{-}$production was mimicked by the $\mathrm{mK}_{\mathrm{ATP}}$ channel opener diazoxide and blocked by preventing its opening with 5-HD and glibenclamide, implicating the mitochondria as the source of $\mathrm{O}_{2}^{-}$. Inhibiting the respiratory chain with rotenone or mitochondrial permeability transition (MPT) with cyclosporine A or bongkrekic acid also canceled aldosterone-induced $\mathrm{O}_{2}^{-}$production. In addition, aldosterone effect depended on NADPH oxidase and phosphoinositide 3-kinase activation, as apocynin and wortmannin, respectively, inhibited it. EGF ( $0.1 \mu \mathrm{g} /$ $\mathrm{mL}$ ) similarly increased $\mathrm{O}_{2}^{-}$, although in this case MR antagonists had no effect, suggesting that EGFR transactivation occurred downstream from MR activation. Inhibition of $\mathrm{mK}_{\mathrm{ATP}}$ channels, the respiratory chain, or MPT did not prevent Akt phosphorylation, supporting that it happened upstream of the mitochondria. Importantly, cardiomyocytes were confirmed as a source of aldosterone induced mitochondrial ROS production in experiments performed in isolated cardiac myocytes.

These results allow us to speculate that the beneficial effects of MR antagonists in heart failure may be related to a decrease in oxidative stress.
\end{abstract}

(c) 2013 Elsevier Ltd. All rights reserved.

\section{Introduction}

The renin-angiotensin-aldosterone system is activated during heart failure (HF). Mineralocorticoid receptor (MR) antagonists have been shown to decrease morbidity and mortality not only in patients with severe HF [1] and after myocardial infarction [2] but also in patients with HF class II of the NYHA functional class [3]. The mechanism by which this inhibition induces beneficial effects, however, has not yet been completely clarified $[4,5]$. On the other hand, a deleterious increase in oxidative stress has been recognized in $\mathrm{HF}$ [6-8], and endothelial dysfunction is linked to this abnormality [9].

Abbreviations: HF, heart failure; MR, mineralocorticoid receptor; ROS, reactive oxygen species; $\mathrm{mK}_{\mathrm{ATP}}$, mitochondrial ATP-dependent potassium; EGFR, epidermal growth factor receptor; MPT, permeability transition pore; 5-HD, 5-hydroxydecanoate; CsA, cyclosporine A; DHE, dihydroethidium.

* Corresponding author at: Centro de Investigaciones Cardiovasculares, Facultad de Ciencias Médicas, UNLP, Calle 60 y 120, 1900 La Plata. Argentina. Tel./fax: +54 221483 4833.

E-mail address: iennis@med.unlp.edu.ar (I.L. Ennis).

1 Both authors equally contributed to this manuscript.
A role for aldosterone in increasing reactive oxygen species (ROS) production in smooth muscle cells, cardiac myocytes, and other tissues has been reported recently, but the intracellular signaling pathway involved in this phenomenon in the myocardium remains unknown [10-13]. In the current study, experiments were performed in rat myocardium and isolated cardiac myocytes to analyze in detail the mechanism underlying aldosterone-induced myocardial $\mathrm{O}_{2}^{-}$production. Our results indicate that aldosterone induces the opening of mitochondrial ATP-dependent potassium ( $\mathrm{mK}_{\mathrm{ATP}}$ ) channels via a non-genomic mechanism that relies on MR-dependent epidermal growth factor receptor (EGFR) transactivation, increasing mitochondrial ROS production.

\section{Methods}

\subsection{Animals}

All the procedures followed during this investigation conform to the Guide for the Care and Use of Laboratory Animals published by the US National Institutes of Health (NIH Publication No. 85-23, revised 1996) 
and the experimental protocol was approved by the Animal Welfare Committee of La Plata School of Medicine. Rats (body weight $300-400 \mathrm{~g}$ ) were anesthetized by intraperitoneal injection of sodium pentobarbital ( $35 \mathrm{mg} / \mathrm{kg}$ body weight) and hearts rapidly excised when plane three of phase III of anesthesia was reached.

\subsection{Construction and production of lentiviral vectors}

DNA encoding for siRNA against the MR ( siRNA $_{M R}$ ) or the scrambled sequence ( siRNA $_{S C R}$ ) was inserted in the lentiviral vector backbone PPT.CDsRed2.H1 as previously described [14]. Sequence for siRNA $A_{M R}$ was obtained from the work of Wang et al. [15] and subcloned, at the BamHI cloning site $\left(5^{\prime}\right)$ and Pacl cloning site $\left(3^{\prime}\right)$, following the H1 RNA Polymerase promoter, to generate PPT.CDsRed2.H1.siRNA $A_{M R}$.

\subsection{Injection of lentiviral vector}

Four-month-old male Wistar rats were injected with lentivirus at two sites in the anterolateral wall of the left ventricle as described before [14]. Four weeks after injection animals were sacrificed, heart removed and sliced. Some slices were used to measure $\mathrm{O}_{2}^{-}$production and others were immediately processed to obtain a protein homogenate and stored at $-70{ }^{\circ} \mathrm{C}$ for immunoblot analysis.

\subsection{Myocardial slices}

Left ventricular myocardial slices $(1 \times 5 \mathrm{~mm})$ were obtained from anesthetized 4-month-old male Wistar rats and incubated in KrebsHepes assay buffer as previously described [16].

\subsection{Cell isolation}

Rat ventricular myocytes were isolated from 4-month-old Wistar rats according to the technique described previously [17]. Myocytes were kept in $1 \mathrm{mmol} / \mathrm{L} \mathrm{CaCl} 2 \mathrm{~K}-\mathrm{H}$ solution at room temperature (20$22{ }^{\circ} \mathrm{C}$ ) until use.

\subsection{Measurement of ROS production}

\subsubsection{In myocardial slices}

Myocardial $\mathrm{O}_{2}^{-}$production was measured by the lucigenin-enhanced chemiluminescence method as previously described [16]. Since high lucigenin concentrations $(>20 \mu \mathrm{mol} / \mathrm{L})$ may favor redox cycling, we used $5 \mu \mathrm{mol} / \mathrm{L}$ lucigenin, at which the amount of artifacts has been proven insignificant [18]. For each intervention evaluated the lucigenin-chemiluminescence signal was normalized to milligrams of dry weight tissue per minute and expressed relative to the basal production.

\subsubsection{In isolated cardiomyocytes}

Freshly isolated cardiomyocytes were loaded with $10 \mu \mathrm{mol} / \mathrm{L} \mathrm{5-}$ (and-6)-chloromethyl-2',7'-dichlorodihydrofluorescein diacetate, acetyl ester (CM-H2DCFDA, Invitrogen) in $\mathrm{K}-\mathrm{H}$ solution for 30 min at $37{ }^{\circ} \mathrm{C}$ in dark. This dye is deacetylated intracellularly by non-specific esterase, which was further oxidized by cellular peroxides to the fluorescent compound 2,7-dichlorofuorescein (DCF), which reported $\mathrm{H}_{2} \mathrm{O}_{2}$ levels [19]. Cardiomyocytes were washed with $\mathrm{K}-\mathrm{H}$ solution to remove dye excess, placed in six-well plates (a different well for each treatment) and excited at $495 \mathrm{~nm}$. Emission spectra were acquired trough a $510 \mathrm{~nm}$ filter with a Nikon camera attached to an inverted Nikon Eclipse TE2000-S microscope. Photographs were taken immediately in control or stimulated cells (aldosterone $10 \mathrm{nmol} / \mathrm{L}$, or EGF $0.1 \mu \mathrm{mol} / \mathrm{L}$ ) every $3 \mathrm{~min}$, during $18 \mathrm{~min}$. The inhibitors and antagonists were placed 10 min before stimulus. Image J software was used for image analysis. Results of fluorescence (arbitrary units) vs. time were fitted with lineal function and obtained a slope for each treatment. Results were expressed as \% of control slope.

\subsection{Immunoanalysis by Western blot}

At the end of the experimental protocols cardiac tissue slices were homogenized in lysis buffer ( $300 \mathrm{mmol} / \mathrm{L}$ sacarose; $1 \mathrm{mmol} / \mathrm{L}$ DTT; $4 \mathrm{mmol} / \mathrm{L}$ EGTA, protease inhibitors cocktail (Complete Mini Roche); $20 \mathrm{mmol} / \mathrm{L}$ Tris-HCl, pH 7.4) for determination of EGFR and Akt phosphorylation; and in $50 \mathrm{mM}$ Tris- $\mathrm{HCl}, \mathrm{pH} 7.4$ for NADPH oxidase (Nox) and MR expression. Samples were denatured and equal amounts of protein were subjected to PAGE and electrotransferred to PVDF membranes. Membranes were then blocked with non-fat-dry milk and incubated overnight with: anti gp91-phox polyclonal antibody (Santa Cruz Biotechnology, sc-5827); anti-phospho-EGFR (Tyr1173) monoclonal antibody (Cell signaling Technology \# 4407); anti-phospho-Akt polyclonal antibody (Cell Signaling Technology \#4060) or anti-ratMR (antibody 4G5, kindly provided by Dr. Celso Gomez Sanchez). Antibodies against EGFR (Santa Cruz Biotechnologies sc-03) or Akt (Cell Signaling Technology \#9272) respectively were assayed to normalize the amount of the phosphorylated form to the total content of the corresponding protein, while the detection of GAPDH (Millipore MAB374) was used as loading control. Peroxidase-conjugated anti-rabbit (NA934, GE Healthcare Life Sciences) or anti-mouse IgG (NA931, GE Healthcare Life Sciences) was used as secondary antibodies and bands were visualized using the ECL-Plus chemiluminescence detection system (Amersham). Autoradiograms were analyzed by densitometric analysis (Scion Image).

\subsection{Chemicals}

All drugs used in the present study were of analytical reagent. Aldosterone, EGF, lucigenin $(5 \mu \mathrm{mol} / \mathrm{L})$, Tiron $(10 \mathrm{mmol} / \mathrm{L})$, nitro-L-arginine methyl ester (L-NAME $1 \mathrm{mmol} / \mathrm{L}$ ), 5-hydroxydecanoate (5-HD, $100 \mu \mathrm{mol} / \mathrm{L})$, rotenone $(10 \mu \mathrm{mol} / \mathrm{L})$, cycloheximide $(20 \mu \mathrm{g} / \mathrm{mL})$, Mifepristone (RU-486; $1 \mu \mathrm{mol} / \mathrm{L})$, spironolactone $(10 \mu \mathrm{mol} / \mathrm{L})$, KT 5823 $(1 \mu \mathrm{mol} / \mathrm{L})$, wortmannin $(10 \mathrm{nmol} / \mathrm{L})$, cyclosporine A (CsA, $0.5 \mu \mathrm{mol} / \mathrm{L})$ and bongkrekic acid $(10 \mu \mathrm{mol} / \mathrm{L})$ were purchased from Sigma. PP1 $(20 \mu \mathrm{mol} / \mathrm{L})$ was purchased from Biomol. Eplerenone $(10 \mu \mathrm{mol} / \mathrm{L})$ was kindly donated by Gador SA, Argentina. Apocynin $(300 \mu \mathrm{mol} / \mathrm{L})$ was from FLUKA. Glibenclamide $(50 \mu \mathrm{mol} / \mathrm{L})$ was purchased from RBI. AG $1478(1 \mu \mathrm{mol} / \mathrm{L})$ and MMP inhibitor $(3 \mu \mathrm{mol} / \mathrm{L})$ were from Calbiochem.

\subsection{Statistics}

Data are expressed as mean \pm SEM. Differences between groups were assessed by one-way ANOVA followed by Student-NewmanKeuls test. $\mathrm{P}<0.05$ was considered significant.

\section{Results}

We explored the effect of aldosterone on cardiac $\mathrm{O}_{2}^{-}$production by the lucigenin-enhanced chemiluminescence method in myocardial slices [16]. Aldosterone induced a dose-dependent increase in the lucigenin-chemiluminescence signal indicating a stimulatory effect of the hormone on myocardial $\mathrm{O}_{2}^{-}$production (Fig. 1A). To investigate the underlying signaling pathway involved in this effect as well as the source of $\mathrm{O}_{2}^{-}$, we performed experiments to evaluate the influence of $10 \mathrm{nmol} / \mathrm{L}$ aldosterone in the presence of different inhibitors. This concentration of aldosterone is one of the most frequently used for in vitro studies $[10,11,20,21]$ and showed submaximal stimulation of $\mathrm{O}_{2}^{-}$production. Absolute baseline values among groups were not statistically different (Supplemental Fig. 1). Two different MR antagonists, spironolactone and eplerenone completely blocked the increased $\mathrm{O}_{2}^{-}$ production induced by aldosterone. Notably, the glucocorticoid receptor antagonist RU-486 (mifepristone) had no effect. Interestingly, the effect 


\section{A}


$\mathrm{B}$

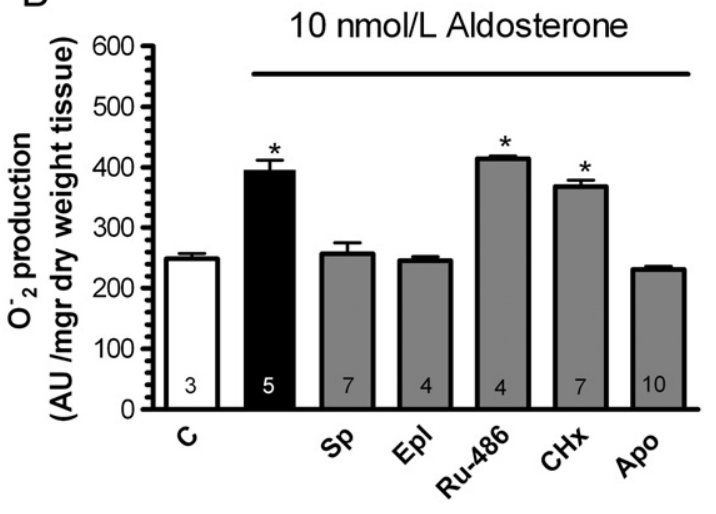

$\mathrm{D}$

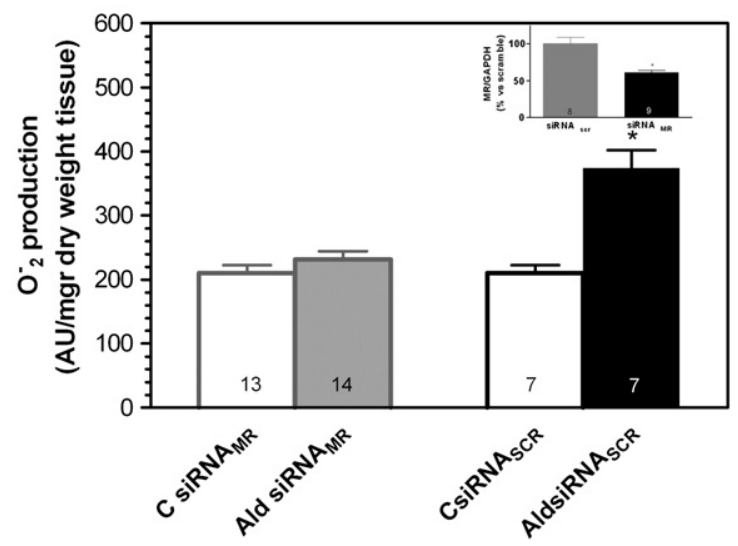

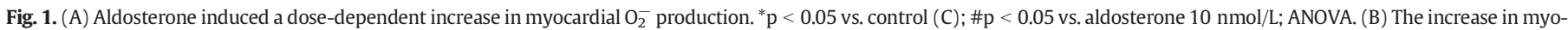

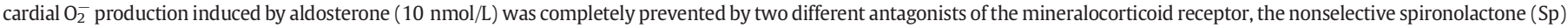

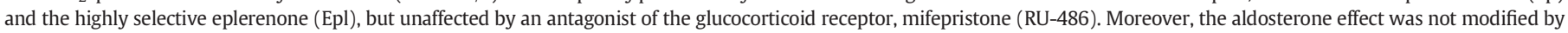

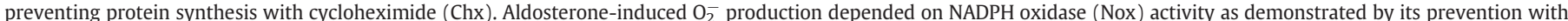

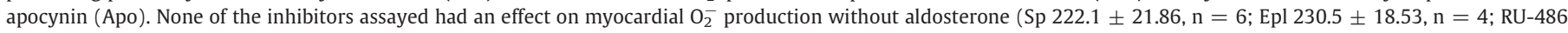

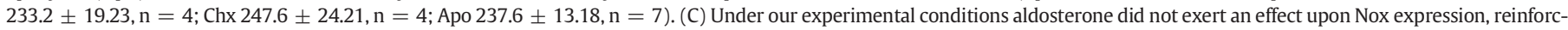

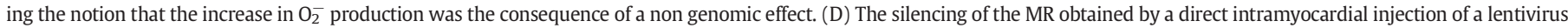

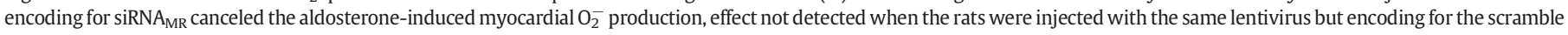

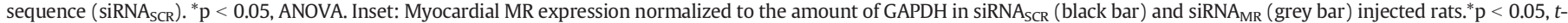
test. The number of samples included in each group is depicted over the corresponding bar.

of aldosterone was unchanged when protein synthesis was prevented by cycloheximide, supporting that this was a non-genomic effect of the hormone. Apocynin inhibited aldosterone-induced $\mathrm{O}_{2}^{-}$production, suggesting the latter's dependence on Nox activity (Fig. 1B). In agreement with the cycloheximide data, Nox content was not modified by aldosterone under our experimental conditions, reinforcing the notion that the increase in $\mathrm{O}_{2}^{-}$production was the consequence of a non-genomic effect (Fig. 1C).

Since pharmacological MR inhibitors may have effects not related to MR blockade [22,23], aldosterone-induced myocardial $\mathrm{O}_{2}^{-}$production was also tested after silencing the MR with siRNA technology. A lentivirus encoding for the fluorescent protein DsRed plus the siRNA $A_{M R}$ or

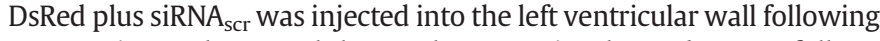
an experimental protocol that we have previously used successfully to silence myocardial $\mathrm{Na}^{+} / \mathrm{H}^{+}$exchanger [14]. After 4 weeks of the lentiviral injection and in order to confirm the spreading of the lentivirus, we assessed DsRed fluorescence on histological sections of siRNA $\mathrm{MR}^{-}$and siRNA $A_{\text {scr-injected rat hearts, as well as on non-injected hearts used as }}$ controls. Representative confocal images are shown in Supplemental Fig. 2. Similar to the results obtained when measuring MR protein expression by Western blot, the DsRed signal reveals a patchy distribution approximately affecting $50 \%$ of the myocardium of the lentiviral-injected hearts while no signal was detected in the sham operated ones. At this time point, aldosterone was unable to increase myocardial $\mathrm{O}_{2}^{-}$production despite the modest decrease in myocardial MR protein expression (Fig. 1D). The effectiveness of the technique used to silence the myocardial MR might be enhanced by the spread of the siRNA from cell to cell through connexins, as proposed by Kizana et al. [24] Taken together, these results suggest that aldosterone stimulates Nox-inducing myocardial $\mathrm{O}_{2}^{-}$production and that this effect depends on MR but not on protein synthesis.

Because the mitochondria is the main source of stimulated myocardial $\mathrm{O}_{2}^{-}$production and small amounts of Nox-produced $\mathrm{O}_{2}^{-}$favors mitochondrial production/release of greater amounts of $\mathrm{O}_{2}^{-}$[25], we designed a new set of experiments to explore mitochondrial involvement in the mechanism triggered by aldosterone. Either 5-HD or glibenclamide was used to prevent $\mathrm{mK}_{\mathrm{ATP}}$ channel opening and rotenone was applied to inhibit complex I of the respiratory chain. Each of these treatments blocked aldosterone-induced myocardial $\mathrm{O}_{2}^{-}$production. Furthermore, when the MPT induction was prevented by cyclosporine A no increase in myocardial $\mathrm{O}_{2}^{-}$was detected; confirming the mitochondrial origin of $\mathrm{O}_{2}^{-}$(Fig. $2 \mathrm{~A}$ ). In order to confirm the relevance of the MPT in aldosterone-induced $\mathrm{O}_{2}^{-}$production, and since cyclosporine A also inhibits the phosphatase calcineurin which might have an impact on the signaling cascade per se [26], the effect of bongkrekic acid - another MPT blocker - was assessed. Similar to the results 

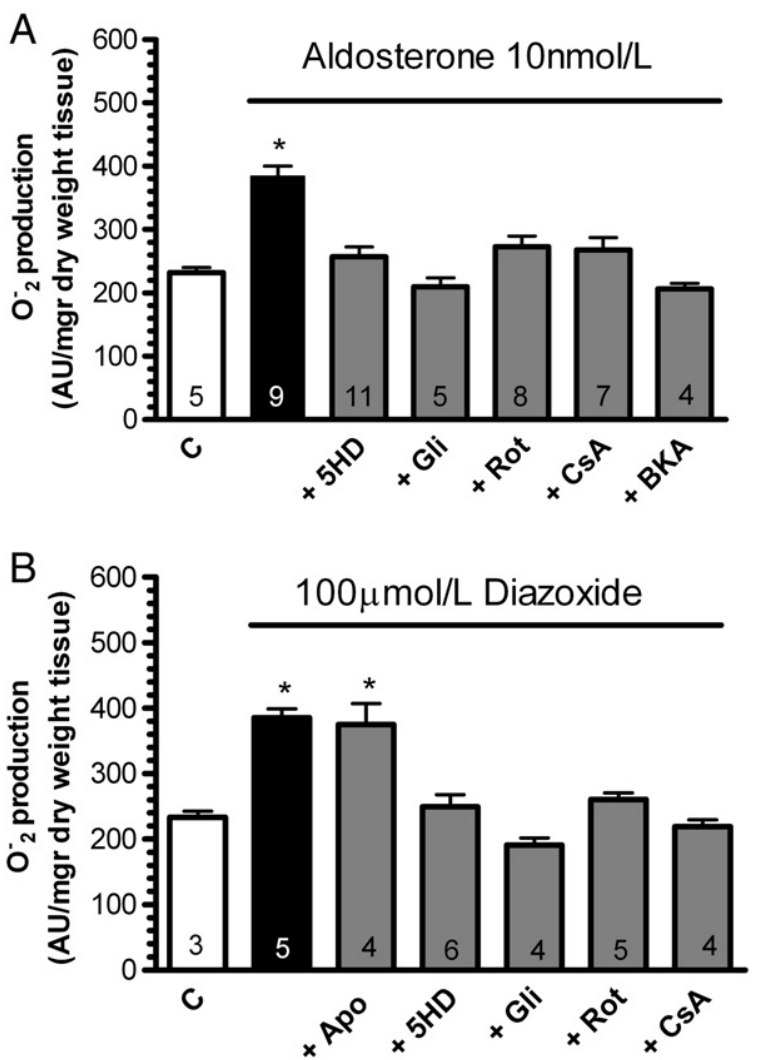

Fig. 2. (A) The mitochondria were revealed as the source for $\mathrm{O}_{2}^{-}$induced by aldosterone because its production was canceled by preventing $\mathrm{mK}_{\mathrm{ATP}}$ channel opening with either 5-hydroxydecanoate (5-HD) or glibenclamide (Gli) as well as by inhibiting complex I of the respiratory chain with rotenone (Rot) and the mitochondrial permeability transition pore opening with cyclosporine A (CSA) or bongkrekic acid (BKA). (B) The opening of $\mathrm{mK}_{\text {ATP }}$ channels with diazoxide $(100 \mu \mathrm{mol} / \mathrm{L})$ increased myocardial $\mathrm{O}_{2}{ }^{-}$production at a similar magnitude to aldosterone $(10 \mathrm{nmol} / \mathrm{L})$. Diazoxide-induced ROS production was canceled by 5-HD, Gli, Rot and CsA but not by Apo. None of the inhibitors assayed had an effect on myocardial $\mathrm{O}_{2}^{-}$production without aldosterone or diazoxide (Apo $237.6 \pm 13.18, \mathrm{n}=7$; 5-HD $226.6 \pm 15.18, \mathrm{n}=5$; Gli $198.4 \pm 8.37, \mathrm{n}=3$; Rot $232.6 \pm 8.42, \mathrm{n}=4$; CsA $224.5 \pm 11.59, \mathrm{n}=8$; BKA $221.2 \pm 10.74, \mathrm{n}=3$ ). The number of samples included in each group is depicted over the corresponding bar. ${ }^{*} \mathrm{p}<0.05$ vs. control (C); ANOVA.

obtained with cyclosporine $\mathrm{A}$, bongkrekic acid blunted the stimulatory effect of aldosterone upon myocardial $\mathrm{O}_{2}^{-}$production (Fig. 2A). These results are in line with previous reports supporting that Nox-dependent $\mathrm{O}_{2}^{-}$production triggers the opening of $\mathrm{mK}_{\mathrm{ATP}}$ channels inducing mitochondrial depolarization and subsequent mitochondrial ROS generation, by the so-called "ROS (reactive oxygen species)-induced, ROS-released phenomenon" $[25,27,28]$. To provide further support for the proposal that the opening of $\mathrm{mK}_{\mathrm{ATP}}$ channels represents a critical step in the aldosterone-triggered signaling pathway leading to $\mathrm{O}_{2}^{-}$production, we performed experiments using $100 \mu \mathrm{mol} / \mathrm{L}$ diazoxide, a widely accepted $\mathrm{mK}_{\mathrm{ATP}}$ channel opener. Diazoxide induced an increase in myocardial $\mathrm{O}_{2}^{-}$production similar to that induced by $10 \mathrm{nmol} / \mathrm{L}$ aldosterone, but in this case, it was apocynin insensitive. Diazoxide-induced ROS production was blocked by the $\mathrm{mK}_{\mathrm{ATP}}$ channel blockers 5-HD and glibenclamide, inhibition of the respiratory chain with rotenone, and prevention of MPT with cyclosporine A (Fig. 2B). These results suggest that aldosterone triggers $\mathrm{O}_{2}^{-}$production of mitochondrial origin through the opening of $\mathrm{mK}_{\mathrm{ATP}}$ channels.

Recent evidence supports that MR activation elicits its non-genomic effects in smooth and cardiac muscle cells at least in part by transactivation of the EGFR [29-32]. Moreover, aldosterone activates metalloproteinases that can induce the ectoshedding of the HB-EGF ligand for the EGFR [10,32]. Therefore, we explored the involvement of EGFR transactivation in aldosterone-induced myocardial $\mathrm{O}_{2}^{-}$

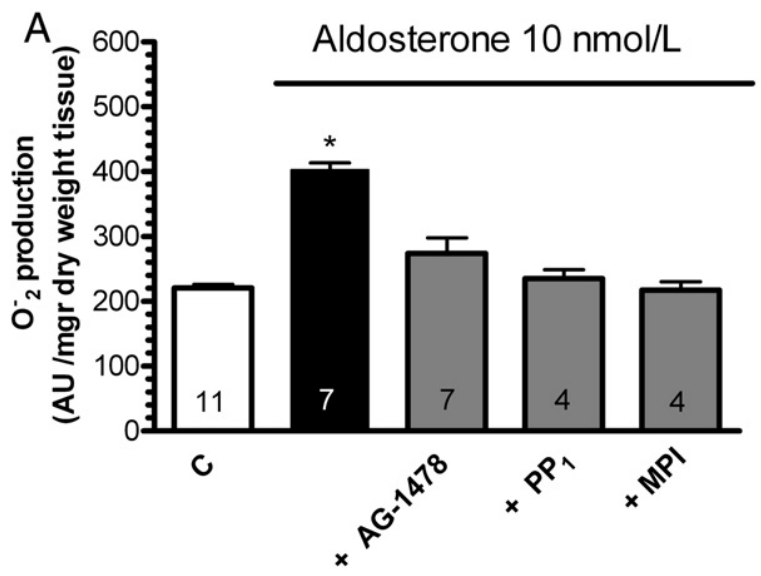

B

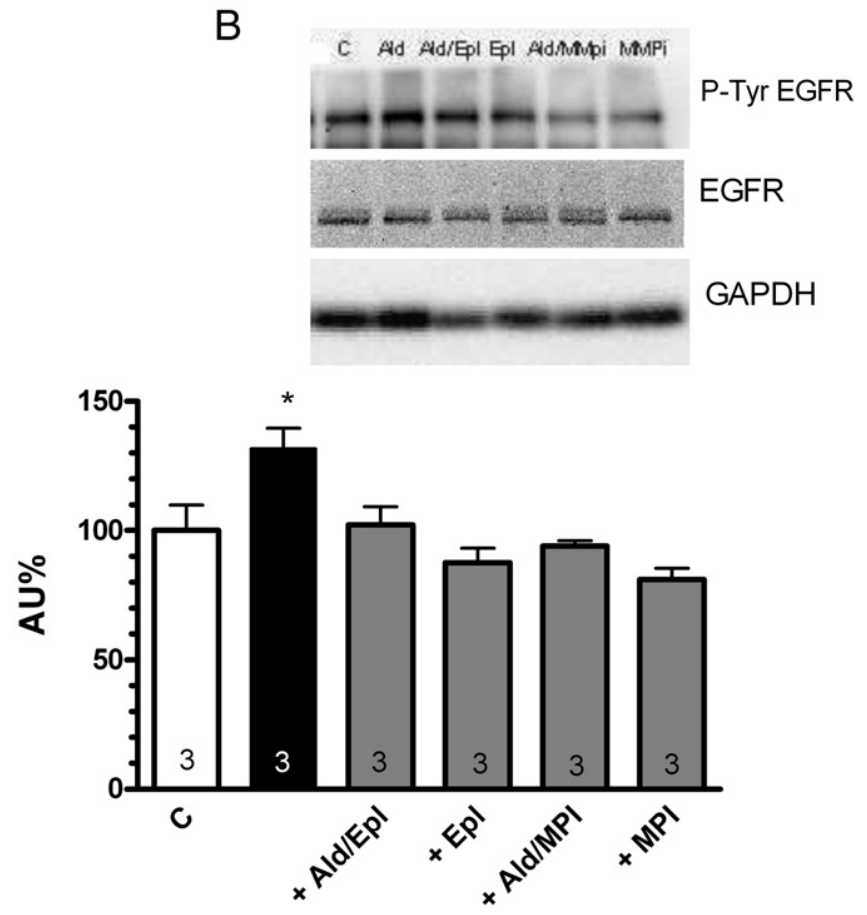

Fig. 3. EGFR transactivation was involved in aldosterone-induced myocardial $\mathrm{O}_{2}^{-}$production. AG-1478, an antagonist of the EGFR; PP1, an inhibitor of the c-Src kinase and MPI, a broad spectrum metalloproteinase inhibitor abolished aldosterone $(10 \mathrm{nmol} / \mathrm{L})$-induced myocardi$\mathrm{al} \mathrm{O}_{2}^{-}$production. It is important to highlight that AG1478, PP1 and MPI alone did not modify basal myocardial $\mathrm{O}_{2}^{-}$production $(239.9 \pm 12.32, \mathrm{n}=5 ; 237.3 \pm 7.43, \mathrm{n}=4$ and $206.2 \pm 9.5, \mathrm{n}=4$, respectively). The number of samples included in each group is depicted over the corresponding bar. *p $<0.05$ vs. control (C); ANOVA.

production. As Fig. 3 shows, AG1478, an antagonist of the EGFR, abolished the effect of $10 \mathrm{nmol} / \mathrm{L}$ aldosterone on $\mathrm{O}_{2}^{-}$production. This effect was also abolished by PP1, an inhibitor of the c-Src kinase previously implicated in angiotensin II-induced EGFR transactivation [33]; and by MPI, a broad-spectrum metalloproteinase inhibitor [34]. Aldosterone-induced EGFR transactivation was confirmed by Western blot. As it can be appreciated in Fig. 3B, $10 \mathrm{nmol} / \mathrm{L}$ aldosterone significantly increased EGFR autophosphorylation, an effect prevented not only by eplerenone but also by MPI. Once we found that EGFR transactivation was required for aldosterone-induced myocardial $\mathrm{O}_{2}^{-}$ production we explored the effect of exogenously administered EGF on $\mathrm{O}_{2}^{-}$production. A dose-response curve showed that $0.1 \mu \mathrm{g} / \mathrm{mL}$ EGF increased myocardial $\mathrm{O}_{2}^{-}$production to levels similar to those elicited by $10 \mathrm{nmol} / \mathrm{L}$ aldosterone (Fig. 4). Inhibition of the EGFR with AG1478 suppressed the effect of exogenous EGF, but Src kinase inhibition with PP1did not, supporting the idea that aldosterone activates Src upstream EGF binding to EGFR in the chain of events leading to 
EGFR transactivation and that Src kinase is not involved in the signaling triggered by the activated EGFR conducting to mitochondrial ROS production under our experimental conditions. Apocynin prevented the effect of EGF indicating its dependence on Nox activation. Furthermore, 5$\mathrm{HD}$, glibenclamide, and rotenone inhibited EGF-stimulated $\mathrm{O}_{2}^{-}$production, confirming that the mitochondria were the source for the increase in $\mathrm{O}_{2}^{-}$(Fig. 4).

As noted above, it has been suggested that small amounts of cytosolic Nox-dependent $\mathrm{O}_{2}^{-}$production induce the opening of the $\mathrm{mK}_{\mathrm{ATP}}$ channel and further mitochondrial $\mathrm{O}_{2}^{-}$generation through a "ROS induced ROS release" phenomenon [25,27,35]. Downey's group proposed an alternative mechanism for the opening of the $\mathrm{mK}_{\mathrm{ATP}}$ channels after EGFR transactivation that involves the PI3K/Akt pathway, nitric oxide synthase (NOS), and protein kinase G (PKG) [36]. Therefore, we examined the possible involvement of this pathway in aldosterone-induced mitochondrial $\mathrm{O}_{2}^{-}$production. Wortmannin, an inhibitor of PI3K/Akt, prevented both aldosterone- and EGF-induced mitochondrial $\mathrm{O}_{2}^{-}$production; but PKG inhibition ( $1 \mu \mathrm{mol} / \mathrm{L}$ KT5823) diminished the stimulated $\mathrm{O}_{2}^{-}$production by only about $50 \%$. Increasing the concentration of KT5823 to $5 \mu \mathrm{mol} / \mathrm{L}$ yielded no additional inhibitory effect (aldosterone $43 \pm 7 \%, \mathrm{n}=3$ and EGF $47.3 \pm 8 \%, \mathrm{n}=3$ over control), supporting that PKG inhibition with this pharmacologic compound was at its maximal effect (Fig. 5). Moreover, NOS inhibition with L-NAME also partially diminished aldosterone-stimulated $\mathrm{O}_{2}^{-}$production $(163.1 \pm 5.5, \mathrm{n}=8$ vs. $134.8 \pm 5.9, \mathrm{n}=5$; $\mathrm{p}<0.05$ for aldosterone and aldosterone + L-NAME respectively), suggesting that PKG and NOS have a role in this signaling pathway. Further studies will be necessary to elucidate the precise mechanism and relevance of NO and PKG-dependent pathway in aldosterone-induced mitochondrial $\mathrm{O}_{2}^{-}$production.

Since myocardial slices are multicellular preparations composed not only by cardiomyocytes but also smooth muscle cells, endothelial cells and fibroblasts; a new set of experiments was performed in isolated cardiac myocytes in order to confirm that the stimulatory effect of aldosterone on ROS production specifically developed in the cardiomyocytes. Freshly isolated rat ventricular myocytes were incubated in the presence of $10 \mathrm{nmol} / \mathrm{L}$ aldosterone alone or in combination with spironolactone, AG1478, 5-HD, rotenone or bongkrekic acid. ROS production was measured by DCF fluorescence. Aldosterone increased $\mathrm{H}_{2} \mathrm{O}_{2}$ production in isolated cardiomyocytes similar to what was detected in ventricular

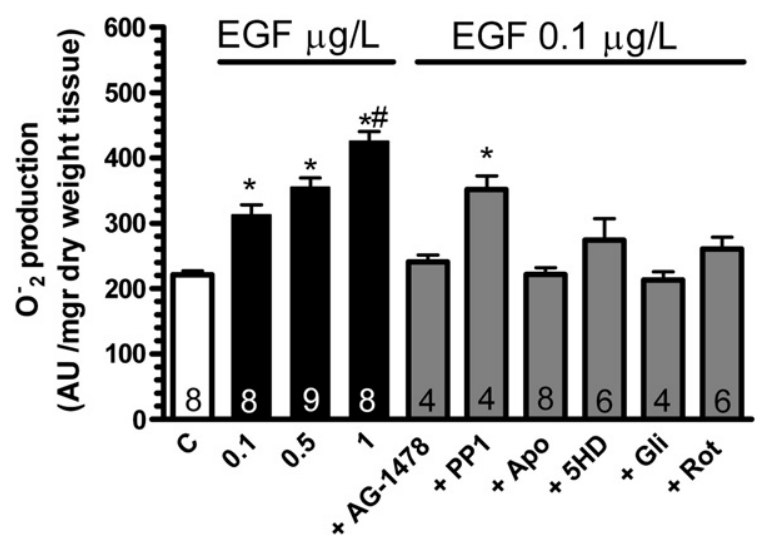

Fig. 4. Exogenously administered EGF dose-dependently stimulated myocardial $\mathrm{O}_{2}^{-}$production, with a concentration of $0.1 \mu \mathrm{g} / \mathrm{mL}$ EGF equipotent to $10 \mathrm{nmol} / \mathrm{L}$ aldosterone. As expected, EGF action was suppressed by the EGFR antagonist AG1478 but not affected by inhibition of Src kinase with PP1, supporting that Src was activated upstream of EGF binding to EGFR. The EGF effect depended on Nox activation as revealed by its prevention with apocynin (Apo), and again the source of $\mathrm{O}_{2}^{-}$was demonstrated to be the mitochondria because its production was blunted by $5-\mathrm{HD}$, Gli and Rot. None of the inhibitors assayed modified basal myocardial $\mathrm{O}_{2}^{-}$production ( $\mathrm{AG} 239.9 \pm 12.32, \mathrm{n}=5$; PP1 $237.3 \pm 7.43, \mathrm{n}=4$; Apo $237.6 \pm 13.18, \mathrm{n}=7$; 5 -HD $226.6 \pm 15.18, \mathrm{n}=5$; Gli $198.4 \pm 8.37, \mathrm{n}=3$; Rot $232.6 \pm 8.42$ ). The number of samples included in each group is depicted over the corresponding bar. ${ }^{*} \mathrm{p}<0.05 \mathrm{vs}$. control (C); \#p $<0.05 \mathrm{vs} .0 .1 \mu \mathrm{g} / \mathrm{mL}$ EGF; ANOVA.

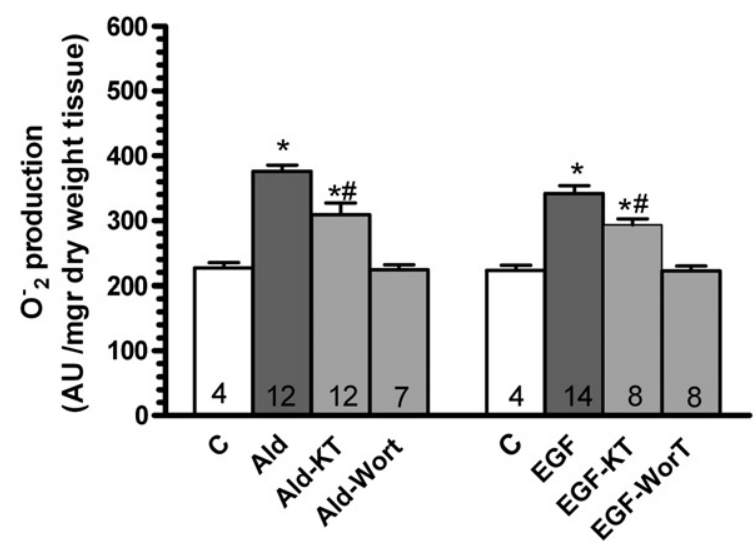

Fig. 5. Both aldosterone (Ald)- and EGF-induced myocardial $\mathrm{O}_{2}^{-}$production were prevented by inhibition of the PI3K/Akt pathway with wortmannin (Wort). PKG inhibition with $1 \mu \mathrm{mol} / \mathrm{L}$ KT5823 (KT) only partially diminished stimulated mitochondrial $\mathrm{O}_{2}^{-}$production. KT5823 or Wort alone did not modify basal $\mathrm{O}_{2}^{-}$production $(230.8+6.38$, $\mathrm{n}=3$ and $212 \pm 8.96, \mathrm{n}=4$, of control respectively). The number of samples included in each group is depicted over the corresponding bar. ${ }^{*} \mathrm{p}<0.05 \mathrm{vs}$. Ald or EGF, respectively; \#p $<0.05$ vs. Ald or EGF plus Wort, respectively; ANOVA.

slices ( $50 \%)$. This effect was prevented not only by antagonizing the MR with spironolactone but also by inhibiting EGFR activation with AG1478, preventing $\mathrm{mK}_{\mathrm{ATP}}$ channel opening with 5-HD, inhibiting complex I of the respiratory chain with rotenone and preventing MPT induction with bongkrekic acid (Fig. 6). Moreover, experiments performed assessing dihydroethidium (DHE) fluorescence indicated that aldosterone stimulated $\mathrm{O}_{2}^{-}$production by the isolated cardiomyocytes (Supplemental Fig. 3). Exogenous EGF $(0.1 \mu \mathrm{g} / \mathrm{mL})$ also increased $\mathrm{H}_{2} \mathrm{O}_{2}$ production in isolated cardiomyocytes, effect that was prevented by AG1478 but not by the blockade of the MR. These data support that the MR and the EGFR are sequentially and unidirectional activated in the isolated myocytes, being the former upstream the later (Fig. 6).

The involvement of PI3K/Akt in the aldosterone-triggered intracellular signaling pathway was confirmed by assessing myocardial Akt phosphorylation by immunoblot. Aldosterone increased Akt phosphorylation, an effect that was prevented by antagonizing the MR with eplerenone or spironolactone and by impeding EGFR transactivation with AG1478 or PI3K activation with wortmannin. Nevertheless, and in contrast to the results obtained for $\mathrm{O}_{2}^{-}$production, Akt phosphorylation was neither affected by precluding $\mathrm{mK}_{\mathrm{ATP}}$ channel opening nor by inhibiting the mitochondrial respiratory chain with rotenone or MPT with bongkrekic acid, confirming that the activation of this kinase occurs upstream of the mitochondria (Fig. 7). None of the pharmacological inhibitors modified AKT phosphorylation when used alone (eplerenone $105.6 \pm 9.2 \%, \mathrm{n}=3$; AG1478 $101.8 \pm 1.6 \%$, $\mathrm{n}=5$; rotenone $93.5 \pm 8.5 \%, \mathrm{n}=7$; 5 -HD $85.1 \pm 9.8 \%, \mathrm{n}=7$; CsA $86.6 \pm 11.5 \%$, $\mathrm{n}=7$; bongkrekic $112.4 \pm 13.8 \%, \mathrm{n}=5$; wortmannin $103.5 \pm 9.48 \%$, $\mathrm{n}=3$ ).

\section{Discusion}

In the present work we provide pharmacological and molecular evidence that aldosterone increases Nox-dependent myocardial $\mathrm{O}_{2}^{-}$and $\mathrm{H}_{2} \mathrm{O}_{2}$ production of mitochondrial origin through intracellular signals that lead to the opening of $\mathrm{mK}_{\mathrm{ATP}}$ channels. We detected $\mathrm{O}_{2}^{-}$production by the lucigenin method in myocardial slices and $\mathrm{H}_{2} \mathrm{O}_{2}$ production by the DCF method in isolated ventricular myocytes. These effects were prevented not only by pharmacologically antagonizing the MR but also by the molecular silencing of the receptor. The opening of $\mathrm{mK}_{\mathrm{ATP}}$ channels would allow $\mathrm{K}^{+}$entry, mitochondrial swelling and MPT induction increasing $\mathrm{O}_{2}^{-}$production [37-39]. These ROS leave the mitochondria probably as $\mathrm{H}_{2} \mathrm{O}_{2}$, because $\mathrm{O}_{2}^{-}$is a short-lived, unstable compound that rapidly generates $\mathrm{H}_{2} \mathrm{O}_{2}$ through spontaneous and enzymatic dismutation. 
A
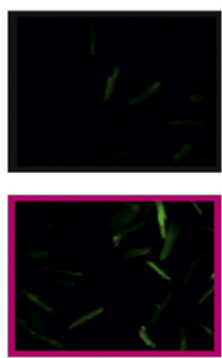

Aldosterone



EGF

C

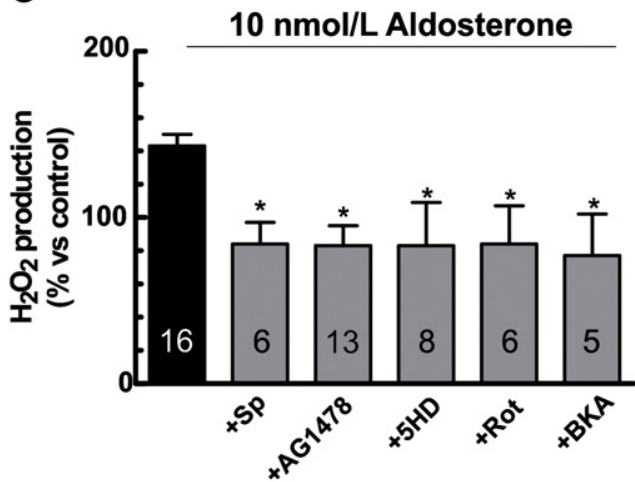

B

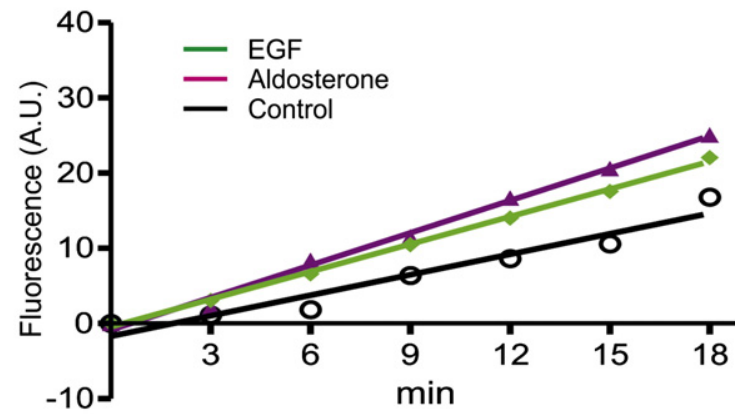

D

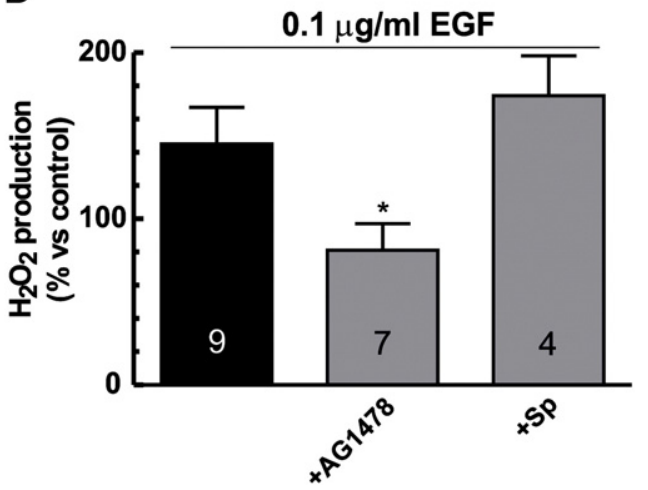









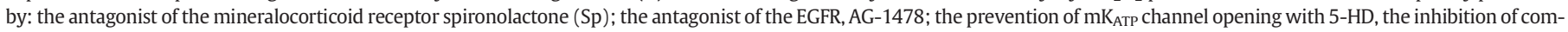

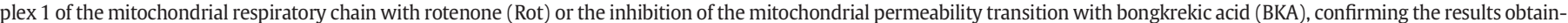

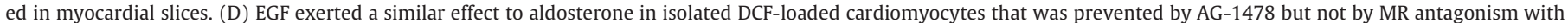

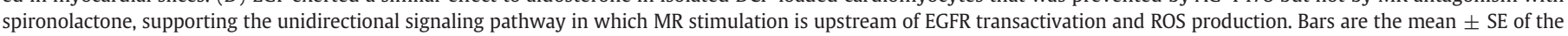

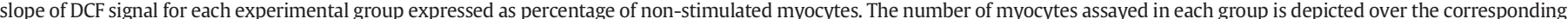

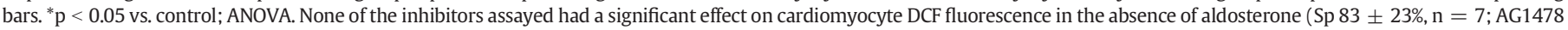
$103 \pm 20 \%, \mathrm{n}=6 ; 5$-HD $88 \pm 19 \%, \mathrm{n}=6$; Rot $93 \pm 28 \%, \mathrm{n}=6$; BKA $71 \pm 11 \%, \mathrm{n}=7$ compared to control).

Aldosterone activates matrix metalloproteinases [10] and probably by this mechanism induces HB-EGF ectoshedding and activation of EGFR. Binding of the released EGF to the EGFR causes dimerization and transphosphorylation of receptor's tyrosine residues. The redox sensitive Src kinase has been reported to be involved both as an upstream step as well as a downstream target of EGFR transactivation $[30,33,40,41,34,42]$ However, our results, in agreement with others, support that Src activation was necessary for aldosterone-induced EGFR transactivation, probably through MMP activation [43].

EGFR transactivation leads to PI3K activation. Our experiments demonstrated that wortmannin inhibition of PI3K abolishes aldosterone-induced mitochondrial $\mathrm{O}_{2}^{-}$production and Akt phosphorylation. Wortmannin also abolished EGF-stimulated mitochondrial $\mathrm{O}_{2}^{-}$production.

The scheme in Fig. 8 summarizes the proposed signaling pathway by which aldosterone leads to increased mitochondrial $\mathrm{O}_{2}^{-} / \mathrm{H}_{2} \mathrm{O}_{2}$ production in the myocardium.

The effect of aldosterone increasing myocardial ROS production has been previously reported $[10,11]$, however, those authors proposed Nox as the source of ROS, and the potential participation of the mitochondria was not explored or even excluded. Also in contrast with the current results, Rude et al. [10] proposed that the activation of matrix metalloproteinases was the result of the increased ROS instead of being a necessary step for aldosterone-induced $\mathrm{O}_{2}^{-} / \mathrm{H}_{2} \mathrm{O}_{2}$ production.
Our data demonstrate that aldosterone-induced myocardial $\mathrm{O}_{2}^{-} / \mathrm{H}_{2} \mathrm{O}_{2}$ production was canceled by two different pharmacologic inhibitors of the MR, namely spironolactone and eplerenone. However, a recent report by Gros et al. [22] drew attention to the fact that these chemical compounds are capable of abolishing effects other than those mediated by the MR. Therefore, definitive evidence was necessary to confirm the MR-dependence of aldosterone-induced $\mathrm{O}_{2}^{-}$production. To this aim, we performed experiments silencing the cardiac MR by direct intramyocardial injection of a lentiviral vector coding for a siRNA against the MR in which we confirmed that aldosteroneinduced $\mathrm{O}_{2}^{-}$production was an MR-dependent effect (see Fig. 3). These results are in agreement with a recent report from Fraccarollo et al. [12] in which they showed that cardiomyocyte-specific inactivation of the MR gene ameliorated adverse remodeling after myocardial infarction by attenuating mitochondrial oxidative stress among the main mechanisms. The experiments performed in isolated cardiac myocytes support that these cells are the target for aldosterone and the source of aldosterone-induced ROS production. However, we do not rule out the involvement of other cell types in response to aldosterone in the intact myocardium.

We highlight several important points to discuss related to the data presented here supporting that aldosterone induces mitochondrial $\mathrm{O}_{2}^{-} / \mathrm{H}_{2} \mathrm{O}_{2}$ production by EGFR transactivation-dependent $\mathrm{mK}_{\text {ATP }}$ channel opening in the myocardium. First is the mechanism by which 
A

P-Akt

$\mathrm{Akt}_{\mathrm{T}}$

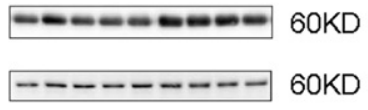

B

Aldosterone $10 \mathrm{nmol} / \mathrm{L}$

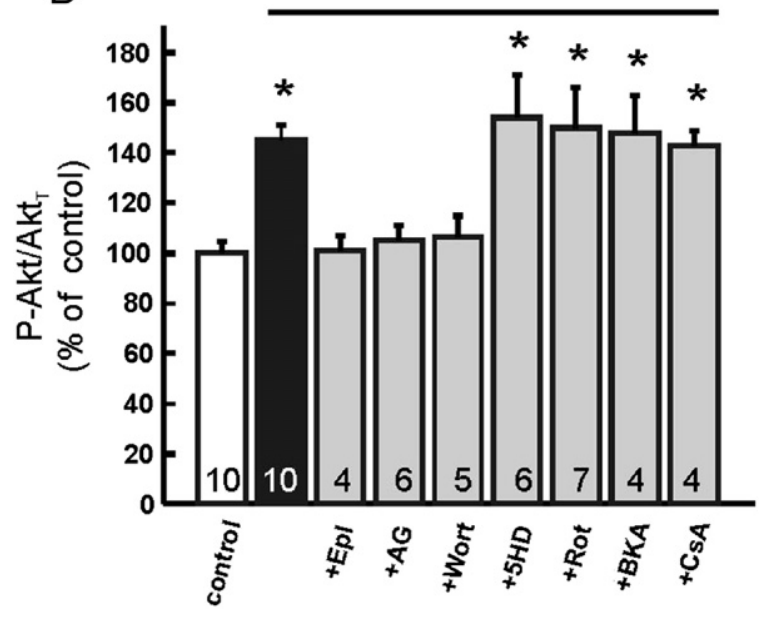

Fig. 7. Aldosterone increased Akt phosphorylation, and the effect that was prevented not only by the MR antagonists, eplerenone (Epl) or spironolactone (Sp) but also by impeding EGFR transactivation with AG1478 or PI3K activation with wortmannin (Wort). However, in contrast to the data obtained for $\mathrm{O}_{2}^{-}$production, Akt phosphorylation was not affected by preventing $\mathrm{mK}_{\mathrm{ATP}}$ channel opening (5-HD or glibenclamide, Gli) or by inhibiting the mitochondrial respiratory chain with rotenone (Rot) or permeability transition pore opening with bongkrekic acid (BKA). These results confirm that the activation of this kinase occurs upstream of the mitochondria. (A) A representative immunoblot with one band corresponding to each experimental group while (B) depicts mean \pm SEM of the experimental groups. The number of samples included in each group is over the corresponding bar. *p < 0.05 vs. Aldosterone or EGF, respectively; ANOVA.

aldosterone induces $\mathrm{mK}_{\mathrm{ATP}}$ channel opening. The apocynin sensitivity of the increased myocardial $\mathrm{O}_{2}^{-}$production induced by aldosterone and EGF would suggest that a localized Nox-dependent ROS production, close to the mitochondria but not detected by the lucigenin method (for review see [44]), would be responsible for opening these channels. Moreover, Akt activates NADPH oxidase in vitro by site-specific phosphorylation of p47phox subunit [45].

Nox 2 and Nox 4 are the Nox isoforms primarily expressed in cardiomyocytes (for review see [46]). It seems reasonable to speculate that Nox2 is most likely involved in the current pathway, because it is apocynin-sensitive. Nox 4 has been recently described as primarily expressed in cardiac mitochondria; however it is not sensitive to apocynin and not regulated by post-translational modifications [47]. The immediate product of Nox enzymes is $\mathrm{O}_{2}^{-}$, but because of both spontaneous and enzymatic dismutation $\mathrm{H}_{2} \mathrm{O}_{2}$ is also rapidly generated from this short-lived, unstable compound, as noted. $\mathrm{O}_{2}^{-}$production occurs either in the extracellular space or in an intraorganelle space. "Redoxosomes" [48] close to the mitochondria could yield a localized production of $\mathrm{O}_{2}^{-}$or $\mathrm{H}_{2} \mathrm{O}_{2}$ capable of inducing $\mathrm{mK}_{\text {ATP }}$ opening and mitochondrial ROS production. Although the $\mathrm{O}_{2}^{-}$does not easily permeate the bilayer membranes, passage through the membrane may occur through anion channels pores in some cases. In vitro experiments conducted in $\mathrm{mK}_{\mathrm{ATP}}$ channels reconstituted into planar lipid bilayers have demonstrated that $\mathrm{O}_{2}^{-}$activates these channels probably by direct action on the sulfhydryl groups of the channel protein [49]. In 2000 Zorov et al. [28] proposed in isolated cardiac myocytes that a source of ROS was able to triggered, through MPT induction, a mitochondrial burst of ROS production derived from the electron transport chain and termed this novel phenomenon "ROS-induced ROS release". Even though the involvement of the $\mathrm{mK}_{\mathrm{ATP}}$ channels in the "ROS-induced

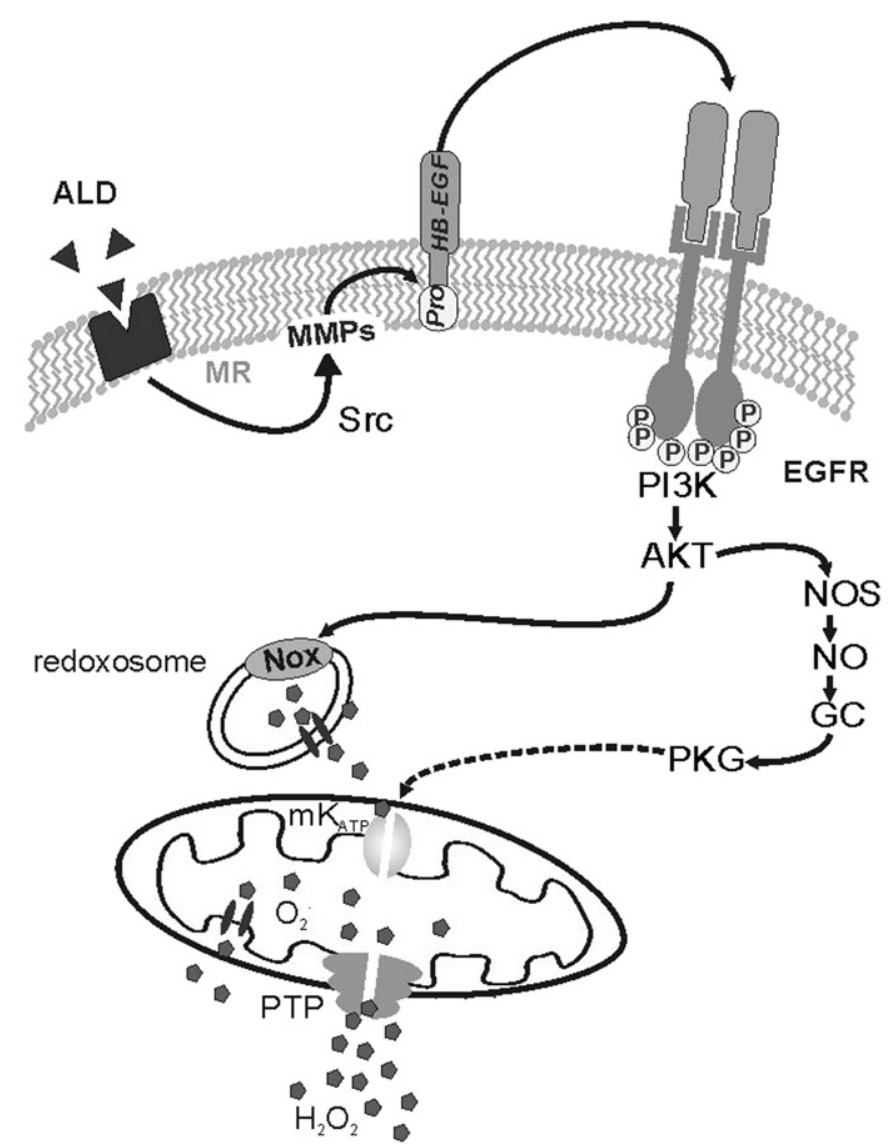

Fig. 8. Schematic summary of the signaling pathway proposed to be triggered by aldosterone in the myocardium leading to an increase in mitochondrial $\mathrm{O}_{2}^{-}$production. We can speculate that the opening of $\mathrm{mK}_{\mathrm{ATP}}$ channels, preceding the increase in mitochondrial $\mathrm{O}_{2}^{-}$production, is the result of the "ROS-induced ROS release" phenomenon since apocynin (Apo) completely abolished mitochondrial $\mathrm{O}_{2}^{-}$production. The role played by PKG would probably be to increase the sensitivity of $\mathrm{mK}_{\mathrm{ATP}}$ channels to ROS; however further research would be necessary to completely elucidate the mechanism involved as well as its relevance.

ROS release" phenomenon was not explored at that time, it was later confirmed by others [25].

In addition to the direct opening of $\mathrm{mK}_{\mathrm{ATP}}$ channels by ROS, another mechanism has been proposed to explain the opening of $\mathrm{mK}_{\mathrm{ATP}}$ channels. Investigators analyzing the cardioprotective effect of $\mathrm{G}_{\mathrm{i}}$-coupled receptor agonists proposed that EGFR transactivation stimulates the PI3K/Akt pathway and nitric oxide production leading to a PKGmediated opening of $\mathrm{mK}_{\text {ATP }}$ channels and increased $\mathrm{O}_{2}^{-}$production [50-52]. At this point, whether PKG directly phosphorylates $\mathrm{mK}_{\mathrm{ATP}}$ channels to open them or instead activates some intermediate is unclear. Our results showing that PKG inhibition can diminish but not fully suppress aldosterone-induced mitochondrial $\mathrm{O}_{2}^{-}$production are in agreement, at least partially, with the above-described findings.

The possibility of both ROS and PKG participating in the opening of $\mathrm{mK}_{\mathrm{ATP}}$ channels after exposing the myocardium to aldosterone deserves consideration. In our case, we can speculate, based on the fact that apocynin completely abolished aldosterone-induced mitochondrial $\mathrm{O}_{2}^{-}$ production, that PKG activation essentially increases the sensitivity of $\mathrm{mK}_{\text {ATP }}$ channels to $\mathrm{O}_{2}^{-}$favoring their opening. Further research would be needed to completely clarify the relative importance of each of these mechanisms.

Also important and independent of the mechanism mediating $\mathrm{mK}_{\text {ATP }}$ channel opening is the involvement of MPT in the aldosteroneresponse. Cyclosporine abolished aldosterone-induced $\mathrm{O}_{2}^{-}$production in the current work (Fig. 2). Contrary to previous ideas, MPT induction does not necessarily imply a fatal breakdown of mitochondrial 
membrane potential and cell death; transient opening appears to be a normal phenomenon, at least when the duration is short $[28,39]$. Transient openings of this pore stimulate a quantal mode of $\mathrm{O}_{2}^{-}$production by the respiratory chain, called "superoxide flashes", in diverse cell types under resting conditions that are controlled by a novel functional coupling between the MPT and the complexes of the respiratory chain [39]. Because of this functional coupling, we might expect that the increased $\mathrm{O}_{2}^{-}$production induced by $\mathrm{mK}_{\text {ATP }}$ channel opening would be linked to MPT pore formation and opening.

The experiments described herein provide insight into the mechanism by which aldosterone increases myocardial $\mathrm{O}_{2}^{-}$production, allowing these results for some speculation about putative clinical implications. If aldosterone increases myocardial $\mathrm{O}_{2}^{-}$production, inhibition of the MR would prevent oxidative stress, a widely recognized deleterious feature in HF. Furthermore, experiments in animal models suggest that NHE-1 activation is harmful in HF having its inhibition beneficial consequences [53-56]. Additionally, the activation of NHE- 1 by ROS is well validated $[16,41,57,58]$. Moreover, recent experiments from our laboratory demonstrate that aldosterone increases NHE-1 activity likely by the same intracellular pathway as that described here, leading to mitochondrial $\mathrm{O}_{2}^{-}$production [32]. Therefore, it seems reasonable to speculate that aldosterone inhibition might "deactivate" the ROSinduced NHE-1 activation and by this mechanism at least partially contribute to the beneficial effects of MR antagonists.

It is interesting and puzzling that the intracellular signals reported herein to explain the increase in mitochondrial ROS production induced by aldosterone are similar to those proposed to underlie myocardial protection from ischemia-reperfusion injury by pre/post-conditioning [36]. We think that at least two aspects may be critical in determining these opposing consequences: a-the whole map of signaling molecules activated by the stimulus; and b-the amount of mitochondrial ROS produced. It is interesting to note that in the case of ischemia-reperfusion injury protection $\mathrm{mK}_{\mathrm{ATP}}$ were proposed to be activated by PKG while in our case PKG pharmacologic inhibition only partially inhibited aldosterone effect. Moreover, aldosterone induced mitochondrial ROS production was completely abrogated by preventing EGFR activation with AG1478, while the protection brought about by preconditioning by a similar pathway was not [51].

With respect to the amount of ROS produced, we can speculate that small quantities possibly trigger protective signaling pathways [59], while greater amounts favor MPT induction and cardiac damage. We evidenced that aldosterone induces MPT opening while in the case of cardiac protection the prevention of MPT induction seems to be critical.

\section{Conclusions}

In the present work pharmacological and molecular evidence is provided supporting that aldosterone stimulates Nox-dependent myocardial $\mathrm{O}_{2}^{-}$and $\mathrm{H}_{2} \mathrm{O}_{2}$ production of mitochondrial origin through EGFR transactivation and intracellular signals that lead to the opening of $\mathrm{mK}_{\text {ATP }}$ channels. Aldosterone effect was blocked not only by pharmacologically interfering with the MR but also by genetically silencing this receptor. Since MR antagonists, by a not yet elucidated mechanism, decrease morbidity and mortality in heart failure patients for whom oxidative stress is usual, it seems reasonable to speculate that a decrease in myocardial oxidative stress is implicated in the cardiac beneficial effects of MR antagonist.

\section{Acknowledgments}

This work was supported in part by grants PICT 25475 and 078 from Agencia Nacional de Promoción Científica of Argentina to Dr. Horacio E. Cingolani and Dr. Gladys Chiappe de Cingolani, respectively. We specially thank Fabian Nishida for histological technical assistance as well as Gador SA, Buenos Aires, Argentina for kindly providing us eplerenone.

\section{Disclosure statement}

None declared.

\section{Appendix A. Supplementary data}

Supplementary data to this article can be found online at http://dx. doi.org/10.1016/j.yjmcc.2013.12.004.

\section{References}

[1] Pitt B, Zannad F, Remme WJ, Cody R, Castaigne A, Perez A, et al. The effect of spironolactone on morbidity and mortality in patients with severe heart failure. Randomized Aldactone Evaluation Study Investigators. N Engl J Med 1999;341:709-17.

[2] Pitt B, Remme W, Zannad F, Neaton J, Martinez F, Roniker B, et al. Eplerenone, a selective aldosterone blocker, in patients with left ventricular dysfunction after myocardial infarction. N Engl J Med 2003;348:1309-21.

[3] Zannad F, McMurray JJ, Krum H, van Veldhuisen DJ, Swedberg K, Shi H, et al. Eplerenone in patients with systolic heart failure and mild symptoms. N Engl J Med 2011;364:11-21.

[4] Martinez FA. Aldosterone inhibition and cardiovascular protection: more important than it once appeared. Cardiovasc Drugs Ther 2010;24:345-50.

[5] Grossmann C, Gekle M. New aspects of rapid aldosterone signaling. Mol Cell Endocrinol 2009;308:53-62.

[6] Giordano FJ. Oxygen, oxidative stress, hypoxia, and heart failure. J Clin Invest $2005 ; 115: 500-8$

[7] Gonzalez DR, Treuer AV, Castellanos J, Dulce RA, Hare JM. Impaired S-nitrosylation of the ryanodine receptor caused by xanthine oxidase activity contributes to calcium leak in heart failure. J Biol Chem 2010;285:28938-45.

[8] Cingolani HE, Plastino JA, Escudero EM, Mangal B, Brown J, Perez NG. The effect of xanthine oxidase inhibition upon ejection fraction in heart failure patients: La Plata Study. J Card Fail 2006;12:491-8.

[9] Tamariz L, Harzand A, Palacio A, Verma S, Jones J, Hare J. Uric acid as a predictor of allcause mortality in heart failure: a meta-analysis. Congest Heart Fail 2011;17:25-30.

[10] Rude MK, Duhaney TA, Kuster GM, Judge S, Heo J, Colucci WS, et al. Aldosterone stimulates matrix metalloproteinases and reactive oxygen species in adult rat ventricular cardiomyocytes. Hypertension 2005;46:555-61.

[11] Hayashi H, Kobara M, Abe M, Tanaka N, Gouda E, Toba H, et al. Aldosterone nongenomically produces NADPH oxidase-dependent reactive oxygen species and induces myocyte apoptosis. Hypertens Res 2008;31:363-75.

[12] Fraccarollo D, Berger S, Galuppo P, Kneitz S, Hein L, Schutz G, et al. Deletion of cardiomyocyte mineralocorticoid receptor ameliorates adverse remodeling after myocardial infarction. Circulation 2011;123:400-8.

[13] Zhu X, Manning Jr RD, Lu D, Gomez-Sanchez CE, Fu Y, Juncos LA, et al. Aldosterone stimulates superoxide production in macula densa cells. Am J Physiol Renal Physiol 2011:301:F529-35.

[14] Perez NG, Nolly MB, Roldan MC, Villa-Abrille MC, Cingolani E, Portiansky EL, et al. Silencing of NHE-1 blunts the slow force response to myocardial stretch. J Appl Physiol 2011:111:874-80.

[15] Wang X, Skelley L, Cade R, Sun Z. AAV delivery of mineralocorticoid receptor shRNA prevents progression of cold-induced hypertension and attenuates renal damage. Gene Ther 2006;13:1097-103.

[16] Caldiz CI, Garciarena CD, Dulce RA, Novaretto LP, Yeves AM, Ennis IL, et al. Mitochondrial reactive oxygen species activate the slow force response to stretch in feline myocardium. J Physiol 2007;584:895-905.

[17] Aiello EA, Cingolani HE. Angiotensin II stimulates cardiac L-type $\mathrm{Ca}(2+)$ current by a $\mathrm{Ca}(2+)$ - and protein kinase C-dependent mechanism. Am J Physiol 2001;280: H1528-36.

[18] Li Y, Zhu H, Kuppusamy P, Roubaud V, Zweier JL, Trush MA. Validation of lucigenin (bis-N-methylacridinium) as a chemilumigenic probe for detecting superoxide anion radical production by enzymatic and cellular systems. J Biol Chem 1998;273:2015-23.

[19] Gioda CR, de Oliveira Barreto T, Primola-Gomes TN, de Lima DC, Campos PP, Capettini Ldos S, et al. Cardiac oxidative stress is involved in heart failure induced by thiamine deprivation in rats. Am J Physiol 2010;298:H2039-45.

[20] Chai W, Garrelds IM, Arulmani U, Schoemaker RG, Lamers JM, Danser AH. Genomic and nongenomic effects of aldosterone in the rat heart: why is spironolactone cardioprotective? Br J Pharmacol 2005; 145:664-71.

[21] Maron BA, Zhang YY, Handy DE, Beuve A, Tang SS, Loscalzo J, et al. Aldosterone increases oxidant stress to impair guanylyl cyclase activity by cysteinyl thiol oxidation in vascular smooth muscle cells. J Biol Chem 2009;284:7665-72.

[22] Gros R, Ding Q, Sklar LA, Prossnitz EE, Arterburn JB, Chorazyczewski J, et al. GPR30 expression is required for the mineralocorticoid receptor-independent rapid vascular effects of aldosterone. Hypertension 2011:57:442-51.

[23] Mihailidou AS, Loan Le TY, Mardini M, Funder JW. Glucocorticoids activate cardiac mineralocorticoid receptors during experimental myocardial infarction. Hypertension 2009:54:1306-12.

[24] Kizana E, Chang CY, Cingolani E, Ramirez-Correa GA, Sekar RB, Abraham MR, et al. Gene transfer of connexin43 mutants attenuates coupling in cardiomyocytes: novel basis for modulation of cardiac conduction by gene therapy. Circ Res 2007; 100:1597-604. 
[25] Kimura S, Zhang GX, Nishiyama A, Shokoji T, Yao L, Fan YY, et al. Role of NAD(P)H oxidase- and mitochondria-derived reactive oxygen species in cardioprotection of ischemic reperfusion injury by angiotensin II. Hypertension 2005;45:860-6.

[26] Weinbrenner C, Liu GS, Downey JM, Cohen MV. Cyclosporine A limits myocardial infarct size even when administered after onset of ischemia. Cardiovasc Res 1998;38:676-84.

[27] Brandes RP. Triggering mitochondrial radical release: a new function for NADPH oxidases. Hypertension 2005;45:847-8.

[28] Zorov DB, Filburn CR, Klotz LO, Zweier JL, Sollott SJ. Reactive oxygen species (ROS)induced ROS release: a new phenomenon accompanying induction of the MPT in cardiac myocytes. J Exp Med 2000;192:1001-14.

[29] Lemarie CA, Paradis P, Schiffrin EL. New insights on signaling cascades induced by cross-talk between angiotensin II and aldosterone. J Mol Med 2008;86:673-8.

[30] Montezano AC, Callera GE, Yogi A, He Y, Tostes RC, He G, et al. Aldosterone and angiotensin II synergistically stimulate migration in vascular smooth muscle cells through c-Src-regulated redox-sensitive RhoA pathways. Arterioscler Thromb Vasc Biol 2008;28:1511-8.

[31] Huang S, Zhang A, Ding G, Chen R. Aldosterone-induced mesangial cell proliferation is mediated by EGF receptor transactivation. Am J Physiol Renal Physiol 2009;296: F1323-33.

[32] De Giusti VC, Nolly MB, Yeves AM, Caldiz CI, Villa-Abrille MC, Chiappe de Cingolani GE, et al. Aldosterone stimulates the cardiac $\mathrm{Na}(+) / \mathrm{H}(+)$ exchanger via transactivation of the epidermal growth factor receptor. Hypertension 2011;58:912-9.

[33] Seshiah PN, Weber DS, Rocic P, Valppu L, Taniyama Y, Griendling KK. Angiotensin II stimulation of $\mathrm{NAD}(\mathrm{P}) \mathrm{H}$ oxidase activity: upstream mediators. Circ Res 2002;91:406-13.

[34] Krieg T, Cui L, Qin Q, Cohen MV, Downey JM. Mitochondrial ROS generation following acetylcholine-induced EGF receptor transactivation requires metalloproteinase cleavage of proHB-EGF. J Mol Cell Cardiol 2004;36:435-43.

[35] Doughan AK, Harrison DG, Dikalov SI. Molecular mechanisms of angiotensin IImediated mitochondrial dysfunction: linking mitochondrial oxidative damage and vascular endothelial dysfunction. Circ Res 2008;102:488-96.

[36] Downey JM, Krieg T, Cohen MV. Mapping preconditioning's signaling pathways: an engineering approach. Ann N Y Acad Sci 2008;1123:187-96.

[37] Costa AD, Quinlan CL, Andrukhiv A, West IC, Jaburek M, Garlid KD. The direct physiological effects of mitoK(ATP) opening on heart mitochondria. Am J Physiol 2006;290:H406-15.

[38] Garciarena CD, Caldiz CI, Correa MV, Schinella GR, Mosca SM, Chiappe de Cingolani GE. $\mathrm{Na}+/ \mathrm{H}+$ exchanger- 1 inhibitors decrease myocardial superoxide production via direct mitochondrial action. J Appl Physiol 2008;105:1706-13.

[39] Wang W, Fang H, Groom L, Cheng A, Zhang W, Liu J, et al. Superoxide flashes in single mitochondria. Cell 2008;134:279-90.

[40] Touyz RM, Wu XH, He G, Salomon S, Schiffrin EL. Increased angiotensin II-mediated Src signaling via epidermal growth factor receptor transactivation is associated with decreased C-terminal Src kinase activity in vascular smooth muscle cells from spontaneously hypertensive rats. Hypertension 2002;39:479-85.

[41] Villa-Abrille MC, Caldiz CI, Ennis IL, Nolly MB, Casarini MJ, de Cingolani GE Chiappe, et al. The Anrep effect requires transactivation of the epidermal growth factor receptor. J Physiol 2010;588:1579-90.

[42] Ulu N, Henning RH, Guner S, Zoto T, Duman-Dalkilic B, Duin M, et al. Intracellular transactivation of epidermal growth factor receptor by alpha1A-adrenoceptor is mediated by phosphatidylinositol 3-kinase independently of activation of extracellular signal regulated kinases $1 / 2$ and serine-threonine kinases in Chinese hamster ovary cells. J Pharmacol Exp Ther 2013;347:47-56.

[43] Ohtsu H, Dempsey PJ, Eguchi S. ADAMs as mediators of EGF receptor transactivation by G protein-coupled receptors. Am J Physiol Cell Physiol 2006;291:C1-C10.

[44] Dikalov S, Griendling KK, Harrison DG. Measurement of reactive oxygen species in cardiovascular studies. Hypertension 2007;49:717-27.

[45] Hoyal CR, Gutierrez A, Young BM, Catz SD, Lin JH, Tsichlis PN, et al. Modulation of p47PHOX activity by site-specific phosphorylation: Akt-dependent activation of the NADPH oxidase. Proc Natl Acad Sci U S A 2003;100:5130-5.

[46] Maejima Y, Kuroda J, Matsushima S, Ago T, Sadoshima J. Regulation of myocardia growth and death by NADPH oxidase. J Mol Cell Cardiol 2011;50:408-16.

[47] Ago T, Kuroda J, Pain J, Fu C, Li H, Sadoshima J. Upregulation of Nox4 by hypertrophic stimuli promotes apoptosis and mitochondrial dysfunction in cardiac myocytes. Circ Res 2010;106:1253-64.

[48] Oakley FD, Abbott D, Li Q, Engelhardt JF. Signaling components of redox active endosomes: the redoxosomes. Antioxid Redox Signal 2009;11:1313-33.

[49] Zhang DX, Chen YF, Campbell WB, Zou AP, Gross GJ, Li PL. Characteristics and superoxide-induced activation of reconstituted myocardial mitochondrial ATPsensitive potassium channels. Circ Res 2001;89:1177-83.

[50] Krieg T, Landsberger M, Alexeyev MF, Felix SB, Cohen MV, Downey JM. Activation of Akt is essential for acetylcholine to trigger generation of oxygen free radicals. Cardiovasc Res 2003;58:196-202.

[51] Krieg T, Qin Q, McIntosh EC, Cohen MV, Downey JM. ACh and adenosine activate PI3kinase in rabbit hearts through transactivation of receptor tyrosine kinases. Am J Physiol 2002;283:H2322-30.

[52] Krieg T, Qin Q, Philipp S, Alexeyev MF, Cohen MV, Downey JM. Acetylcholine and bradykinin trigger preconditioning in the heart through a pathway that includes Akt and NOS. Am J Physiol 2004;287:H2606-11.

[53] Baartscheer A, Hardziyenka M, Schumacher CA, Belterman CN, van Borren MM, Verkerk AO, et al. Chronic inhibition of the $\mathrm{Na}+/ \mathrm{H}+$-exchanger causes regression of hypertrophy, heart failure, and ionic and electrophysiological remodelling. Br J Pharmacol 2008;154:1266-75.

[54] Engelhardt S, Hein L, Keller U, Klambt K, Lohse MJ. Inhibition of $\mathrm{Na}(+)-\mathrm{H}(+)$ exchange prevents hypertrophy, fibrosis, and heart failure in beta(1)-adrenergic receptor transgenic mice. Circ Res 2002;90:814-9.

[55] Nakamura TY, Iwata Y, Arai Y, Komamura K, Wakabayashi S. Activation of $\mathrm{Na}+/ \mathrm{H}+$ exchanger 1 is sufficient to generate $\mathrm{Ca} 2+$ signals that induce cardiac hypertrophy and heart failure. Circ Res 2008;103:891-9.

[56] Cook AR, Bardswell SC, Pretheshan S, Dighe K, Kanaganayagam GS, Jabr RI, et al. Paradoxical resistance to myocardial ischemia and age-related cardiomyopathy in NHE1 transgenic mice: a role for ER stress? J Mol Cell Cardiol 2009;46:225-33.

[57] Garciarena CD, Fantinelli JC, Caldiz CI, Chiappe de Cingolani G, Ennis IL, Perez NG et al. Myocardial reperfusion injury: reactive oxygen species vs. NHE-1 reactivation. Cell Physiol Biochem 2011;27:13-22.

[58] Sabri A, Byron KL, Samarel AM, Bell J, Lucchesi PA. Hydrogen peroxide activates mitogen-activated protein kinases and $\mathrm{Na}+-\mathrm{H}+$ exchange in neonatal rat cardiac myocytes. Circ Res 1998;82:1053-62.

[59] Saotome M, Katoh H, Yaguchi Y, Tanaka T, Urushida T, Satoh H, et al. Transient opening of mitochondrial permeability transition pore by reactive oxygen species protects myocardium from ischemia-reperfusion injury. Am J Physiol 2009;296: H1125-32. 